\title{
Relatedness, economic complexity and convergence across European regions
}

\author{
Tullio Buccellato ' and Giancarlo Corò
}

Economic Research Department, Confindustria. The opinions and views expressed in this paper by the author do not reflect in any way the opinions and views of Confindustria as an institution. Corresponding author: t.buccellato@confindustria.it

Ca' Foscari University, Department of Economics.

\begin{abstract}
The aim of this paper is to analyze how the heterogeneous structure of the European regions has affected their patterns of convergence or divergence. We analyse data collected by Eurostat, from a balanced panel of 191 regions and 55 economic branches over the period 2003-2015. In this way, we are able to describe and capture technological proximity across the regions and analyse how it has evolved over space and time. Limiting the analysis to the manufacturing activities, we are also able to measure the degree of economic complexity of the regional production systems and assess how this affects their patterns of growth.

Our findings suggest that spatial effects tend to push towards convergence, with the Eastern regions that started from relatively low levels of GDP per capita and experienced higher growth rates. Nevertheless, the different level of economic complexity tends to widen the gaps between territories: for example, the German regions, whose economic structures are more complex, have kept on widening the gap between themselves and the other European regions. The two different forces are also interconnected as the Eastern regions combine a relatively low level of GDP per capita with a significant level of economic complexity. During the period considered, the improvement in living standards has corresponded to the upgrade of their manufacturing production structures.
\end{abstract}

Keywords: regional disparities, growth, convergence, structural change, relatedness, economic complexity, spatial effects.. 


\section{Introduction}

From the second half of the 1990s to the 2000s, the EU single market has undergone a period of fast political and economic integration, which experienced an important milestone in 2004, when ten new countries became Member States. At the same time of the EU integration, globalization accelerated worldwide, with a number of important economies, especially China, entering the World Trade Organization; the strengthening of links between countries has boosted trade, capital and migration flows. While it has been beneficial to many people all over the world, the enhanced degree of competition and the continuous speeding up of innovation have also enlarged the economic divide between nations and regions. Highly competitive territories have acquired a key advantage from the enhanced level of export, which, in turn, has brought higher returns on innovation, widening the gap between stronger and weaker regions, in terms of both knowledge and prosperity. As highlighted in recent reports (see Iammarino et al 2018; Rodrìguez-Pose 2017; Demertzis et al. 2019), in the last two decades, the tendency toward a geographical polarization has notably grown. Additionally, in the European Union, the inequality among regions has sharply increased, threatening social cohesion within and between countries and becoming one of the hardest political challenges for governments to deal with.

A key factor explaining the different paths of regional development is the uneven distribution of the productive knowledge, as well as the different learning skills acquired through the experience of the production (Stiglitz and Greenwald 2014). In this sense, the structure of economic systems well captures the set of competences available locally. In fact, convergence clusters often mirror groups of territories with related knowledge basis that tend to show both similar patterns of economic growth and a comparable evolution of the technological development (Boschma 2005). Therefore, the gaps in prosperity across territories are deeply influenced by their stock and the "quality" of the competences available locally; from this perspective, the "convergence clubs" mentioned by Baumol (1986) can be intended as clusters of countries with a similar knowledge basis and institutional setting.

The theory of economic complexity has offered an additional key to interpret the generation and persistence of gaps across nations and regions (Hidalgo C. A., B. Klinger, A.-L. Barabási, R.Hausmann 2007, Hausmann and Hidalgo 2010, Tacchella, Cristelli et al 2012; Hausmann, Hidalgo et al 2013, ), on the basis of the local stock of competences, in terms of its diversification, and their "quality", intended as their ubiquity (the more ubiquitous the less sophisticated). The theory of economic complexity focuses on productive knowledge embedded within real economic goods. However, "accumulating productive knowledge is difficult. For the most part, it is not available in books or on the Internet. It is embedded in brains and human networks. It is tacit and hard to transmit and acquire. It comes from years of experience more than from years of schooling." (Hausmann, Hidalgo et al 2013)

The structure of the economy situated in a given territory is therefore a key factor which explains both the patterns of economic growth and the evolution of the local knowledge. Accordingly, convergence and divergence across countries and regions has a twofold connotation, as it originates from the divide in productive competences and results in disparities in income and wealth. This reconciles the neoclassic perspectives of endogenous growth in terms of knowledge (Lucas 1988; Romer 1986 and 1990) and learning by doing, with the patterns of technological change in the evolutionary economic theory (Nelson and Winter, 1982).

The empirical analysis develops from descriptive statistics of economic development across the regions in the EU28 and discusses such evolution on the basis of the initial level of competences, captured by the structure in the economic branches. We then focus on the period 2003-2015 about which more detailed data are available, both on 191 regions and on 55 economic branches (i.e. comparing structural similarities as the parameter to measure the distance). Specifically, we construct an econometric model which takes into account both spatial and structural characteristics of EU regions to assess how these interactions influence convergence and divergence. Finally, we construct an index of economic complexity and show how it impacts the patterns of growth across the regions.

Our findings suggest that convergence processes in EU are driven mainly by a cluster of manufacturing regions belonging to Eastern European countries. Such regions took advantage of the set of manufacturing competences, developed during the communist era. Over that period, they underwent a process of quick modernization thanks to the fast integration with the value chain of the German and other productive markets. Such regions have been able to upgrade their competences and reach a more complex production process, which also has rapidly improved their level of GDP 
per capita in comparison to other mid-income regions in Western Europe. Divergence has been instead exacerbated by the dynamics of growth of the German regions, which, on average, have outperformed all the other regions, thanks to their highly complex manufacturing production fabrics.

In the next section we briefly introduce stylized facts on convergences and divergences between the European regions. The third section introduces the methodology used to analyze the structural similarity across the regions, it presents the econometric model used and illustrates our empirical findings. Section five concludes.

\section{Stylized facts on convergence/divergence across European regions}

Looking at the patterns of prosperity across European regions over the last two decades, a general improvement in the living standards can be observed, although this has been accompanied by an increase in the absolute gap between richer and poorer regions. In 2000, the bottom group of regions (clustered in the first percentile level of GDP per capita at purchasing power standards, PGDP), had an average PGDP of 4,200 euros; in 2015, the same statistical data increased by more than double the amount, to 9,600 euros (Table 1). The growth pace of the PGDP for the regions at the bottom percentile of the distribution was faster in comparison to those at its top (the top/bottom ratio decreased from 10.3 to 6.2). Even if the absolute divide between the richer and the poorer regions has widened (the difference between the top percentile and the bottom percentile has increased from 39,200 to 49,900 euros), while the overall dispersion (measured by the relative standard deviation) remains stable. Furthermore, the distance between the regions at the top of the distribution and those around the median has been more persistent (the top/median ratio has remained stable at 2.3).

Table 1. Summary statistics of the distribution of income in 2000 and in 2015.

\begin{tabular}{|c|c|c|c|c|c|c|c|c|c|}
\hline \multicolumn{5}{|c|}{2000} & \multicolumn{5}{|c|}{2015} \\
\hline & $\begin{array}{r}\text { Percen- } \\
\text { tiles } \\
\end{array}$ & $\begin{array}{r}\text { Smal- } \\
\text { lest }\end{array}$ & & & & $\begin{array}{r}\text { Percen- } \\
\text { tiles } \\
\end{array}$ & $\begin{array}{r}\text { Smal- } \\
\text { lest }\end{array}$ & & \\
\hline $1 \%$ & 4200 & 3600 & & & $1 \%$ & 9600 & 8400 & & \\
\hline $5 \%$ & 6700 & 4200 & & & $5 \%$ & 13900 & 9500 & & \\
\hline $10 \%$ & 8000 & 4200 & Obs. & 260 & $\begin{array}{l}10 \\
\% \\
\end{array}$ & 15600 & 9600 & Obs. & 269 \\
\hline $25 \%$ & 14250 & 4200 & & & $\begin{array}{l}25 \\
\%\end{array}$ & 20900 & 9900 & & \\
\hline $50 \%$ & 19200 & & Mean & 19225 & $\begin{array}{l}50 \\
\%\end{array}$ & 25900 & & Mean & 27761 \\
\hline & & Largest & $\begin{array}{l}\text { Std. } \\
\text { Dev. }\end{array}$ & 9042 & & & Largest & $\begin{array}{r}\text { Std. } \\
\text { Dev. }\end{array}$ & 13003 \\
\hline $75 \%$ & 23300 & 36000 & & & $\begin{array}{l}75 \\
\%\end{array}$ & 32100 & 59200 & & \\
\hline $90 \%$ & 28500 & 43400 & & & $\begin{array}{l}90 \\
\% \\
\end{array}$ & 39400 & 59500 & & \\
\hline $95 \%$ & 32300 & 48700 & $\begin{array}{l}\text { Skew } \\
\text { ness }\end{array}$ & 2.78 & $\begin{array}{l}95 \\
\%\end{array}$ & 46700 & 76200 & $\begin{array}{l}\text { Skew- } \\
\text { ness }\end{array}$ & 5.0299 \\
\hline $99 \%$ & 43400 & 99100 & $\begin{array}{l}\text { Kur- } \\
\text { tosis }\end{array}$ & 25.36 & $\begin{array}{l}99 \\
\%\end{array}$ & 59500 & 167500 & Kurtosis & 51.61 \\
\hline
\end{tabular}

However, this overall stability hides very diversified paths of convergence and divergence among the regional economies. Fig. 1 gives a quick overview of the change in ranking of the regions (see horizontal axis), compared to the initial level of PGDP (logarithm) in 2003 (see vertical axis). The graph can be sub-divided in four areas. First, the North-East quad, where regions have been climbing up the ranking, even if starting from better-off positions, i.e. exacerbating the divergence by contributing to the gap in the higher end. Second, the North-West quad, where regions have been losing positions in the ranking but started with a relatively high level of PGDP, i.e. fostering the convergence in the high end. Third, the South-West quad, where regions have been losing positions in the ranking, even if they started from relatively poor initial conditions in terms of PGDP, i.e. exacerbating the divergence in the low end. Finally, the South East quad comprises 
regions which have been gaining positions and started from relatively poor initial conditions, i.e. fostering the convergence in the low end. At a first glance, if any convergence took place over the period considered, this happened in the bottom part of the distribution, mainly due to the rapid growth in GDP per capita across regions in Central and Eastern Europe (see also Cuaresma, Doppelhofer and Feldkircher, 2014).

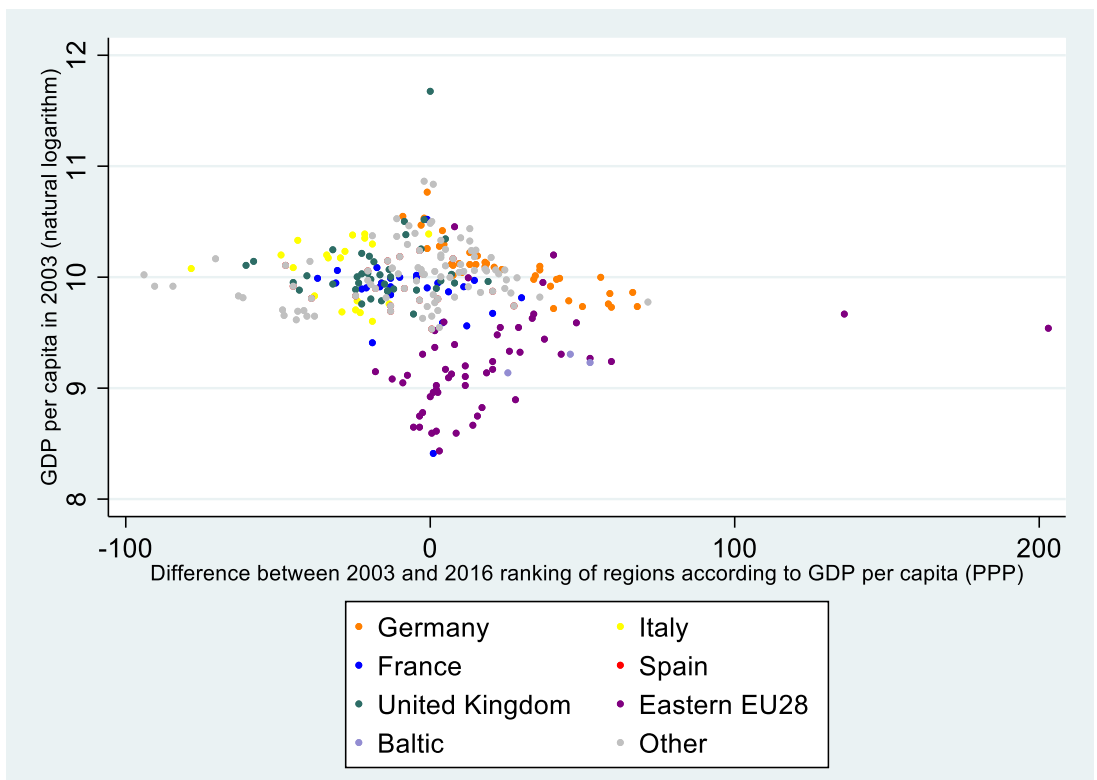

Fig. 1. The regions which contributed more to convergence 2003-2016.

Fig. 2 shows the importance of Eastern European regions in driving the process of convergence. The red fitted line shows that an estimated rate of convergence of $3.1 \%$ (with a p-value below 1\%) took place over the period 2003-2016; such results change substantially when the regions in Eastern Europe are not considered: the beta-coefficient get closer to 0 and loses significance. The regions which have contributed more to such result include: the region surrounding Bucarest in Romania, the Mazovia province and the lower Silesian province in Poland, where Warsaw is located, the Southwest Planning Region in Bulgaria, the region of Sophia, the East area of the Czech Republic.

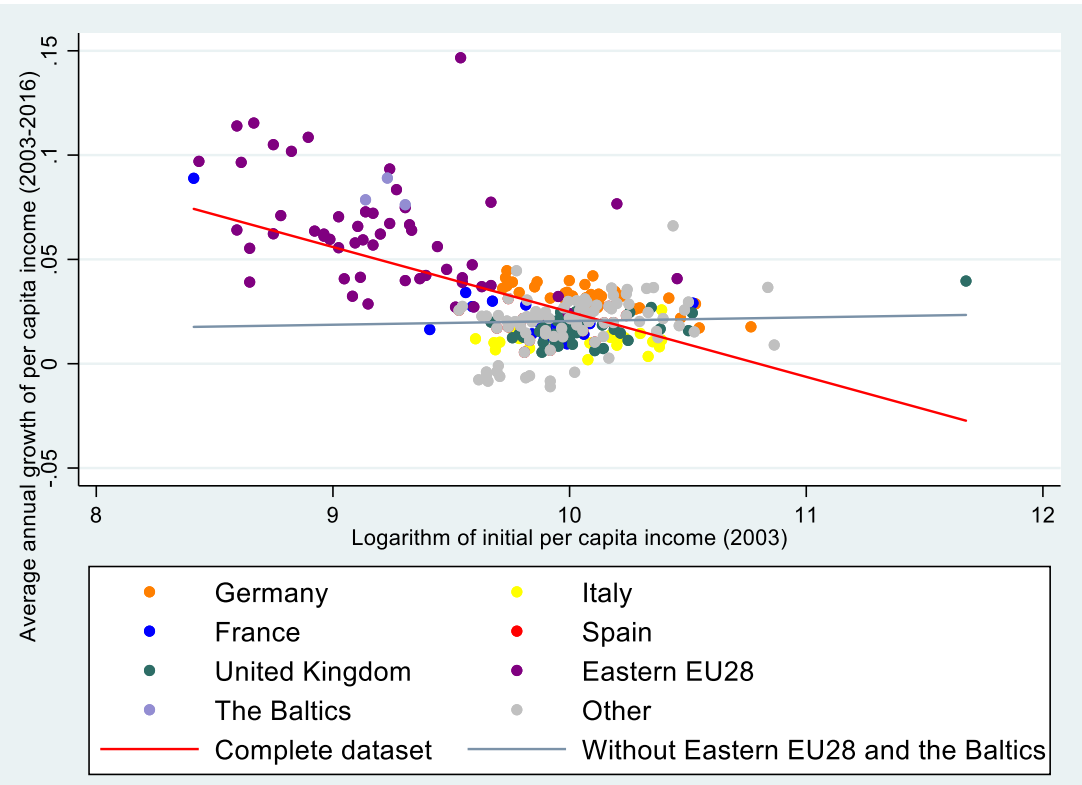

Fig. 2. Convergence across European regions over the period 2003-2016. 
Table 2 reports the top 20 of regions for the number of positions gained in the ranking of PGDP. The first factor that emerges clearly from the table is that geography considerably impacted the success of regions: apart from Malta, the top 20 are only by regions in Eastern Germany and Eastern Europe. Of particular interest in this sense is the analysis of groups of regions starting with a similar and relatively low level of GDP per capita but experiencing different paths of growth and development. For instance, Boltho, Carlin and Scaramozzino (2018) compare the cases of the regions in Eastern Germany and those of the Italian Mezzogiorno, concluding that the former were more successful in catching up with the rest of the country than the latter. This happens because of the higher homogeneity in terms of economic complexity, as national integration, per se, brings convergence in consumption rather than in GDP per capita.

Table 2. Top 20 regions for the number of positions gained in the ranking.

\begin{tabular}{|c|c|c|c|c|c|c|}
\hline NUTS2 & Region & $\begin{array}{l}\text { GDP per } \\
\text { capita in } \\
2003\end{array}$ & $\begin{array}{l}\text { GDP per } \\
\text { capita in } \\
2016\end{array}$ & $\begin{array}{l}\text { Rank- } \\
\text { ing } 2003\end{array}$ & $\begin{array}{r}\text { Rank- } \\
\text { ing } 2016\end{array}$ & $\begin{array}{c}\text { Growth of GDP } \\
\text { per capita between } \\
2003 \text { and } 2016 \text {. }\end{array}$ \\
\hline $\mathrm{RO} 32$ & $\begin{array}{l}\text { București - Il- } \\
\text { fov }\end{array}$ & 13900 & 40400 & 229 & 26 & $14,67 \%$ \\
\hline PL12 & Mazowieckie & 15800 & 31700 & 212 & 76 & $7,74 \%$ \\
\hline MT00 & Malta & 17600 & 27800 & 190 & 119 & $4,46 \%$ \\
\hline DEG0 & Thüringen & 16900 & 26700 & 198 & 130 & $4,46 \%$ \\
\hline DED5 & Leipzig & 19200 & 29000 & 170 & 103 & $3,93 \%$ \\
\hline BG41 & Yugozapaden & 10300 & 22800 & 244 & 184 & $9,34 \%$ \\
\hline DED4 & Chemnitz & 16800 & 25800 & 200 & 141 & $4,12 \%$ \\
\hline DED2 & Dresden & 19000 & 28100 & 172 & 113 & $3,68 \%$ \\
\hline DE40 & Brandenburg & 17300 & 26100 & 193 & 135 & $3,91 \%$ \\
\hline DE24 & Oberfranken & 22000 & 33400 & 116 & 60 & $3,99 \%$ \\
\hline LT00 & Lietuva & 10200 & 22000 & 245 & 193 & $8,90 \%$ \\
\hline PL51 & Dolnoslaskie & 10600 & 22100 & 242 & 190 & $8,35 \%$ \\
\hline DEE0 & $\begin{array}{l}\text { Sachsen- } \\
\text { Anhalt } \\
\end{array}$ & 16900 & 25100 & 198 & 148 & $3,73 \%$ \\
\hline CZ06 & Jihovýchod & 14600 & 23600 & 224 & 176 & $4,74 \%$ \\
\hline EE00 & Eesti & 11000 & 21900 & 240 & 194 & $7,62 \%$ \\
\hline DE93 & Lüneburg & 17800 & 25700 & 188 & 143 & $3,41 \%$ \\
\hline PL41 & Wielkopolskie & 11000 & 21700 & 240 & 197 & $7,48 \%$ \\
\hline DE94 & Weser-Ems & 21800 & 31500 & 122 & 79 & $3,42 \%$ \\
\hline DEB1 & Koblenz & 21600 & 31100 & 125 & 84 & $3,38 \%$ \\
\hline SK01 & $\begin{array}{l}\text { Bratislavskj } \\
\text { Kraj }\end{array}$ & 26900 & 53700 & 47 & 6 & $7,66 \%$ \\
\hline
\end{tabular}

The case of the reunification of Eastern with Western Germany is perhaps emblematic to explain the rapid catch-up of Eastern European regions with the remaining part of the EU. One would think that the reunification between the two German blocks has exemplified the integration of the Eastern economies in the Union. Germany has indeed played an important role, being far the largest foreign investor in the new countries, while Poland has been the most attractive place for German firms. As in the case of the Ost-Länder after the fall of the Berlin wall, Central and Eastern European regions have enjoyed a quick political integration, supported by the EU institutions. They also benefitted from a great amount of resources to modernize the infrastructure thanks to the EU policy of cohesion. Finally, the convergence of the private sector has reached highly competitive standards thanks to the foreign direct investments, especially by German corporations.

A clear example is the quick development of German corporations active in the automotive sector that, after the reunification, have expanded in the Eastern Ländern. For instance, the Eastern Region of Saxony, which hosted the obsolete automotive industry inherited from the communist era at the beginning of the 1990 s, by the early 2000 s had already modernized the automotive clus- 
ter, serving mainly the Volkswagen corporation. A similar case study is the one of Berlin region, thanks to the heavy investments of BMW and Mercedes. Already during the 1990s, in parallel to the wide flows of investments in its Eastern Ländern, Germany had already started to redirect a great part of its foreign direct investments towards Eastern Europe, facilitating the entrance of such countries to the single market in 2004.

The contribution of our research is to investigate whether, in addition to the geographical factors, the initial structure of the regional economies might have played a role in determining their patterns of growth and development. Sharing the point of view of economic complexity, the productive structure of a territory mirrors the pool of knowledge, skills and know-how available at the local level, setting the basis for the learning processes from which long-term economic development originates.

Initial evidence is provided by the analysis of the structural change process for the top performing regions in comparison to the remaining one, over the period 2003-20151. Fig. 3 compares the difference in the productive structure in the initial and in the final year. Top performers had an initial weight of motor vehicles and machinery manufacturing, which was remarkably higher in 2003 and increased even more in 2015. This suggests that the initial competences in these two manufacturing branches have played an important role in the success of the top performing regions, which, in turn, have leveraged on the initial competences to further increase the size and scale of the activities in these branches.

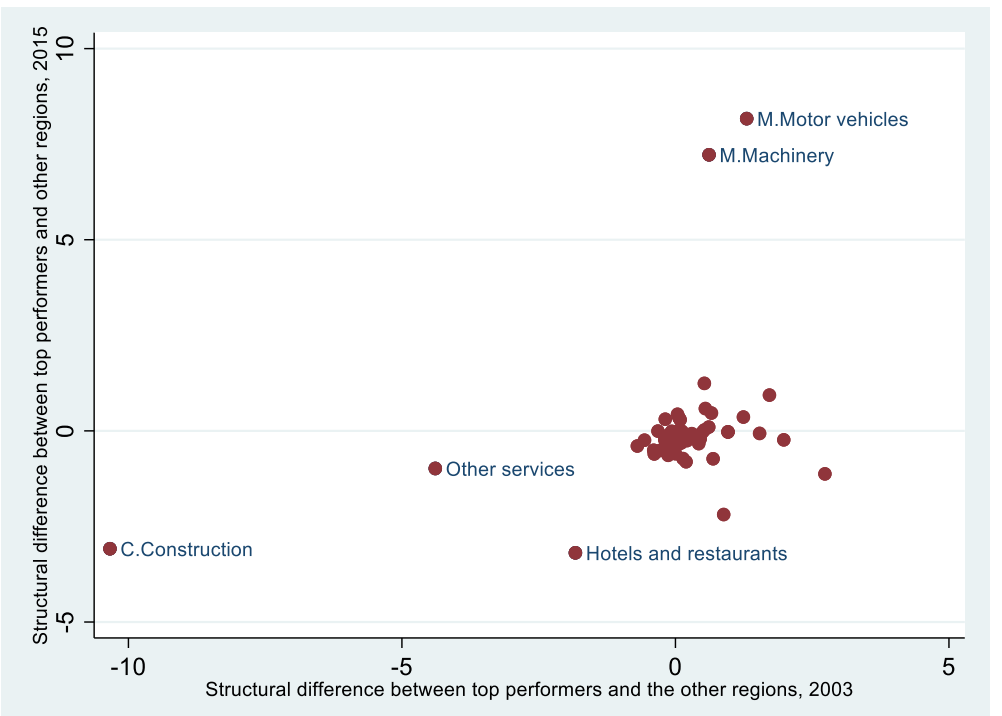

Fig. 3. Structural change in top performers with respect to other regions.

We can also observe that the regions where the specialization in the tourism sector tends to prevail at the beginning of the period, the performance worsens over the period considered. In our opinion, this result is consistent with the assumption of economic complexity, according to which the learning processes are mostly nurtured by the variety of practical knowledge used in manufacturing (Buciuni et al 2014; Hidalgo 2015; Pisano and Shih 2012). Where the tourist supply dominates the economy, there is a tendency to present two effects that are not very helpful for long run growth: first, because the lacking of other industries, tourism demand feeds external production flows, with a low multiplier for the local economy; second, a dominant tourism economy risks to follow the logic of rent seeking, with reduced incentives for learning and innovation.

In general, the reasons of the persistent gaps across regions are multifaceted and find their roots in historical, institutional, technological and geographical factors. Since the 1990s, a large strand of the economic literature has been focusing on identifying the most meaningful determinants of convergence/divergence across countries and regions, following the path explored by Barro and Sala-i-Martin (1991) on the basis of the theoretical implications pointed out by the Solow (1956) and Swan (1956). A wide range of hypotheses on the key factors for development and growth have

To this purpose a mapping has been realized between the two different sector classifications used by Eurostat before and after 2007. Data are available over the full period for 11 regions out of the top 20 and for other 213 regions. Data have been reclassified in 55 economic branches. 
been tested with such stream of models, leading sometimes to contrasting results, depending on the theoretical specification selected - the so called "open-endedness" of growth theories (Brock and Durlauf 2001).

At the same time, the theory of economic complexity proposes an understanding of development based on the social ability to accumulate, share and create productive knowledge, which therefore tend to feed through learning-by-doing processes influenced by the pre-existing economic structure. The economic growth of regions will therefore be stronger if there is a diversified production base that enables the firms to employ and combine complex knowledge.

\section{Capturing structural relatedness across regional production structures}

In this section we propose a model to test how the structure of regions affects its future patterns of economic growth and the process of convergence/divergence with other regions.

The first step is the construction of the structural square matrix, which captures the degree of proximity of the product spaces of each region in comparison with the others. Such matrix has the dimension 191, corresponding to the number of regions for which the structural data are available over the full time span. The variable used is the amount of wages paid in each region and branch, normalized by the total amount per region. Based on this information, we construct a symmetric matrix, in which each cell contains the pair-wise correlation between each region with all the others individually considered. The cells of the matrix are filled up using information on the number of employees collected by Eurostat, available for a balanced panel of 191 regions and 55 economic branches in 2010 and 2015 . The economic structure of each region is normalized by the total number of employees.

We are therefore able to construct a product space characterized by the technological proximity of regions. Such information is then used in a spatial econometric model, which has been found very useful for studying convergence across regions in various geographical contexts (Rey and Montoury 2000; Le Gallo, Ertur and Baoumont 2003; G. Arbia, R. Basile and G. Piras 2005; Buccellato 2007). The originality of the model used in this specification is that we use the lag of the error term to capture relatedness across the regional production systems, in addition to the spatial lag of the dependent variable, to control for the effects of geographical distance across the observations. The model specification can be formally depicted as follows:

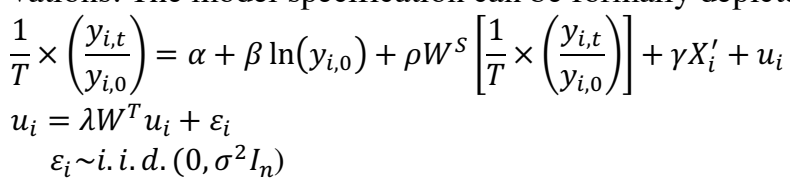

where $y_{i, t}$ is the GDP per capita of region $i$ as of date $t, T$ is the length of the period, $\alpha$ is a constant and $\beta$ is the convergence coefficient, the matrix $X$ contains additional explanatory control variables and the respective vector of associated coefficients $\gamma \cdot W^{S}$ is the space matrix containing the inverse of the geographical distance and $\mathrm{W}^{\mathrm{T}}$ the structural proximity of regional production structures. $\mathrm{u}_{\mathrm{i}}$ is a non-spherical disturbance that is auto-correlated with respect to the degree of similarity of the industrial production fabrics.

As benchmark, Table 3 displays results related to the unconditional convergence for 268 regions for the whole period 2003-2016 and for the two sub-periods 2003-2007 - before the economic crisis - and 2010-2016 -following the crisis but excluding its two initial years. Convergence appears to be taking place over the full period considered (the beta coefficient is in the order of 0.0334 and significant at the $1 \%$ confidence level) with a more pronounced pace in the time span preceding the economic crisis (-0.0396), more than three times faster in comparison with what happened afterwards (-0.0116). The loss of momentum of the convergence process turns out to be evident also from the R-squared which drops from around 0.302 in the earlier period to 0.066 in the end.

Table 3. Unconditional convergence with GLS. 


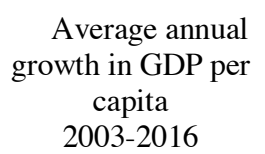

capita

Average annual growth in GDP per capita 2003-2007
Average annual growth in GDP per capita 2008-2016

VARIABLES

\begin{tabular}{lccc} 
Initial GDP per capita in logs & $-0.0334 * * *$ & $-0.0396 * * *$ & $-0.0143 * * *$ \\
& $(0.00327)$ & $(0.00532)$ & $(0.00242)$ \\
Constant & $0.358 * * *$ & $0.445^{* * *}$ & $0.158 * * *$ \\
& $(0.0326)$ & $(0.0531)$ & $(0.0244)$ \\
& & & 268 \\
Observations & 268 & 268 & 0.106 \\
R-squared & 0.382 & 0.302 & \\
\hline Robust standard errors in parentheses & & \\
$* * * \mathrm{p}<0.01, * * \mathrm{p}<0.05, * \mathrm{p}<0.1$ & &
\end{tabular}

Table 4 reports the same results introducing the full model presented above. The number of observations falls from 268 to 191 , i.e. the number of regions for which structural data are available. The sample reduction does not seem to substantially affect the results regarding the convergence coefficients, which, even if with a slightly different magnitude, follow the same pattern over time, i.e. with a slower convergence pace after the economic crisis. Spatial effects are present over the full time span and with a stronger magnitude in the last period. The degree of similarity in the structure of the economies is also significant but loses significance when isolating the years preceding the crisis. These results suggest that the crisis has slow down the convergence processes across EU regions. However, after the crisis, the relatedness of the production structures started to affect more incisively the economic growth of regions, as it appears from the lambda coefficient modelled in the error term, which becomes very strong in magnitude and highly significant.

Table 4. Unconditional convergence with GLS spatial regression including a spatial lag of the dependent variable and an error term auto-correlated according to the regional production structure estimated through 2sls.

(1)

(2)

(3) (4)

(4) (8)

(12)

\begin{tabular}{|c|c|c|c|c|c|c|}
\hline & $\begin{array}{c}\text { Average } \\
\text { annual growth } \\
\text { in GDP per } \\
\text { capita } \\
\text { 2003-2016 }\end{array}$ & $\begin{array}{l}\text { Average } \\
\text { annual } \\
\text { growth in } \\
\text { GDP per } \\
\text { capita } \\
\text { 2003-2007 }\end{array}$ & $\begin{array}{l}\text { Average } \\
\text { annual } \\
\text { growth in } \\
\text { GDP per } \\
\text { capita } \\
\text { 2010-2016 }\end{array}$ & $\begin{array}{l}\text { Average } \\
\text { annual } \\
\text { growth in } \\
\text { GDP per } \\
\text { capita } \\
\text { 2003-2016 }\end{array}$ & $\begin{array}{l}\text { Average } \\
\text { annual } \\
\text { growth in } \\
\text { GDP per } \\
\text { capita } \\
\text { 2003-2007 }\end{array}$ & $\begin{array}{l}\text { Average } \\
\text { annual } \\
\text { growth in } \\
\text { GDP per } \\
\text { capita } \\
\text { 2010-2016 }\end{array}$ \\
\hline \multirow[t]{2}{*}{ Initial GDP per capita in logs } & $\begin{array}{c}- \\
0.0384^{* * *} \\
\end{array}$ & $\begin{array}{c}- \\
0.0423^{* * * *}\end{array}$ & $\begin{array}{c}- \\
0.0120^{* * * *} \\
\end{array}$ & $\begin{array}{c}- \\
0.0331^{* * *} \\
\end{array}$ & $\begin{array}{c}- \\
0.0433^{* * *} \\
\end{array}$ & $\begin{array}{c}- \\
0.0126^{* * *}\end{array}$ \\
\hline & $(0.004)$ & $(0.007)$ & $(0.004)$ & $(0.003)$ & $(0.004)$ & $(0.003)$ \\
\hline \multirow[t]{2}{*}{ Spatial lag of dep.var. } & & & & $0.824 * * *$ & $0.260 * *$ & $0.662 * * *$ \\
\hline & & & & $(0.109)$ & $(0.131)$ & $(0.141)$ \\
\hline Structural lag of in the error term & & & & $33.28 * * *$ & -0.697 & $9.880 * * *$ \\
\hline Observations & 191 & 191 & 191 & 191 & 191 & 191 \\
\hline
\end{tabular}




\begin{tabular}{|c|c|c|c|}
\hline R-squared & 0.446 & 0.320 & 0.071 \\
\hline $\begin{array}{l}\text { Robust standard errors in paren- } \\
\text { theses }\end{array}$ & & & \\
\hline$* * * \mathrm{p}<0.01, * * \mathrm{p}<0.05, * \mathrm{p}<0.1$ & & & \\
\hline
\end{tabular}

Fig. 4 depicts the patterns of structural change across EU regions in terms of manufacturing activities, tending to be more complex as of the mix of competences involved in their production2. All the observations above the line tend to have experienced an increase in their manufacturing activities in 2015 in comparison with 2003. Among those areas which experienced a greater increase appear once again those in Eastern Europe - such result is more evident for the Romanian region of Vest and for the Hungarian regions of Közép-Dunántúl, Észak-Magyarország, NyugatDunántúl. The regions consolidating their top positions are the key locations of manufacturing activities in Germany - Stuttgart, Oberpfalz, Tübingen and Mittelfranken. Instead, French and British regions appeared to have undergone a period of reduction in the manufacturing activities, whereas the Italian regions were distributed close to the line, on average not having changed their structure significantly.

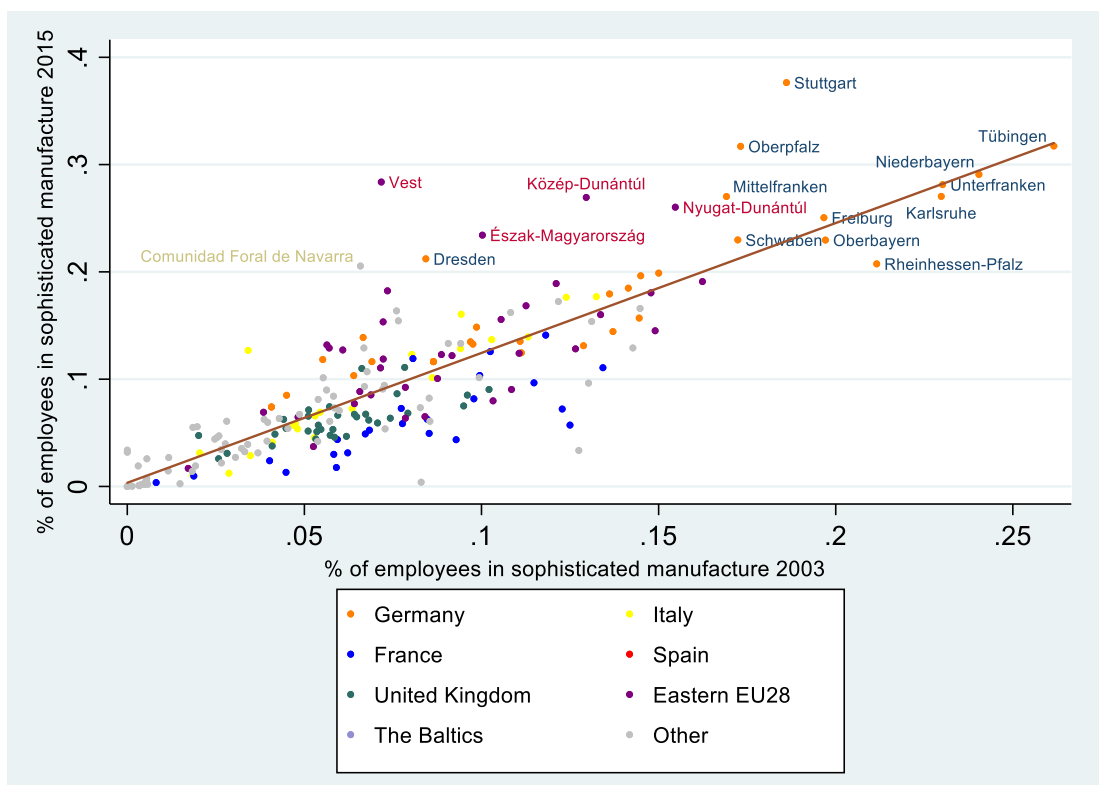

Fig. 4. The evolution in the structure of employees in relation to highly sophisticated sectors.

\footnotetext{
${ }^{2}$ We have aggregated the manufacturing activities relating to the following sectors: chemical, pharmaceutical, electronic, electrical, machinery and motor vehicles.
} 


\section{Economic complexity and regional growth}

The underlying assumption is that territories with comparable production structures display similar degrees of production knowledge and, hence, degree of economic complexity. To assess to what extent economic complexity might have affected the patterns of divergence and convergence across the EU regions, we use information on their production structure and on the average degree of product complexity in each sector, as shown in trade data. We compute a weighted average of product economic complexity, available from the Atlas of Economic Complexity, where the weight is provided by the value of trade of a given product category over the total value of trade, within the two digit HS product. This allows realizing a map between HS and NACE classification to compute the average product complexity of the regional manufacture structures, adopting the share of employees in each industry as weights.

Fig. 5 (next page) shows the relation between GDP per capita and economic complexity in 2003 and in 2010. For countries, the relation tends to be positive. German regions are the ones exhibiting the higher degree of economic complexity associated with the higher level of GDP per capita. Economic complexity tends to capture very well how the divide in knowledge generates gaps in prosperity across the regions. What turns out to be evident, especially in 2003 , is that the Eastern European regions tend to be all below the fitted line. This suggests that, ceteris paribus, such regions have a set of competences that is highly sophisticated in comparison with the income that they exhibit and this would imply a greater distance from their steady state. Therefore, higher growth rates. In 2010, the distance is already reduced but there appear to be still room for growing faster than the other regions.

Not surprisingly, in Fig. 6 (next page), which plots the average annual growth rate of GDP per capita in terms of economic complexity, we observe that, net of the effect of the initial level of GDP per capita, Eastern regions tend to grow faster than the others, generating convergence because they started from relatively low levels of GDP per capita. 

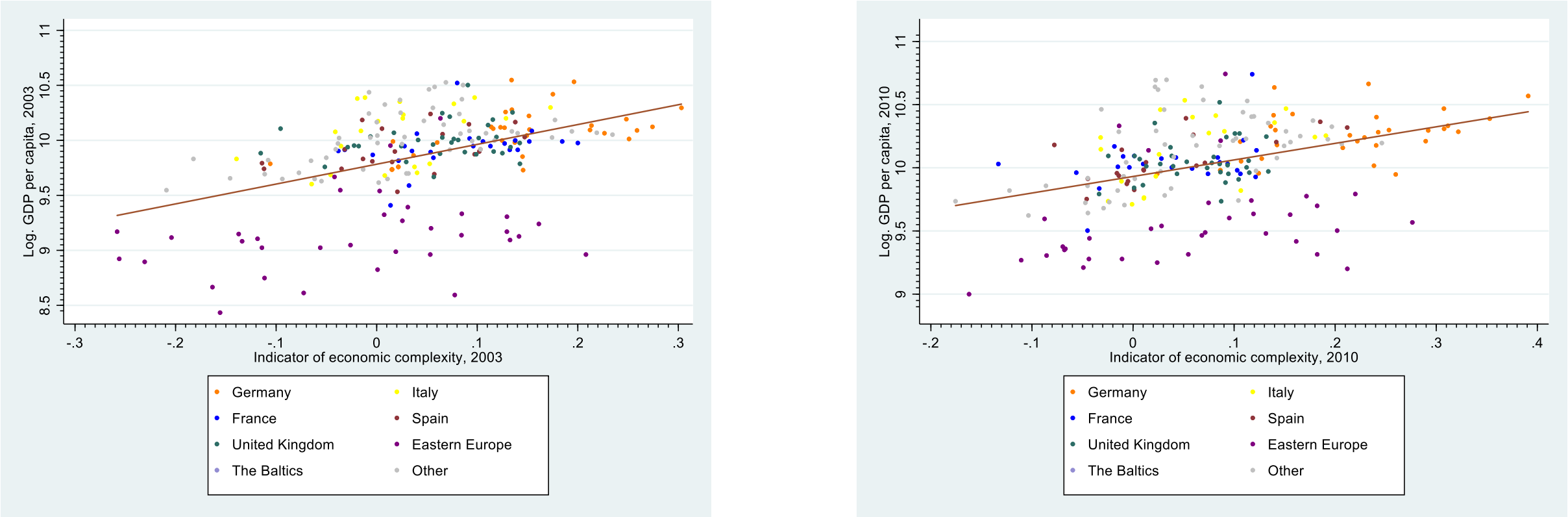

Fig. 5. - economic complexity and GDP per capita across EU regions.
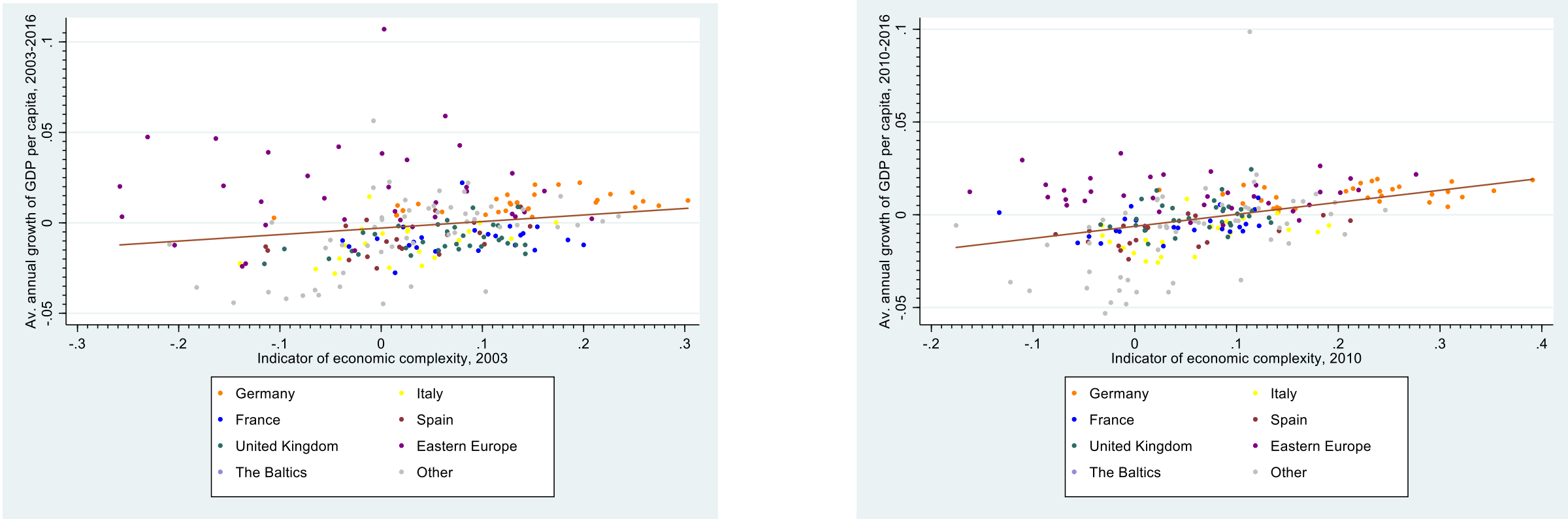

Fig. 6. Economic complexity and average annual growth in gdp per capita across EU regions (net of the effect of initial GDP per capita). 
Table 5 includes the indicator of regional economic complexity in the regression model to assess more precisely its impact on convergence patterns. Over the full period, it turns out to be strong in magnitude and highly significant. In the time span between 2003 and 2007, it remains positive but loses significance and, after the economic crisis, it exhibits stronger magnitude and impact. The convergence coefficient has a stronger magnitude when the one associated to the indicator of economic complexity loses importance. Such a pattern becomes even clearer when the spatial lag of the dependent variable is included. This evidence opens up the way to an additional interpretative hypothesis. In the first part of the sample, the Eastern regions have been catching up with the rest. Following the crisis, the convergence pattern has slow down, as the German regions have accelerated more than the others, generating again divergence.

Table 5. Convergence and economic complexity, GLS and 2SLS.

\begin{tabular}{ccccccc}
\hline & $(1)$ & $(2)$ & $(3)$ & $(4)$ & $(5)$ & $(6)$ \\
\hline & Average & Average & Average & Average & Average & Average \\
& annual & annual & annual & annual & annual & annual \\
& growth in & growth in & growth in & growth in & growth in & growth in \\
& GDP per & GDP per & GDP per & GDP per & GDP per & GDP per \\
VARI & capita & capita & capita & capita & capita & capita \\
ABLES & $2003-2016$ & $2003-2007$ & $2010-2016$ & $2003-2016$ & $2003-2007$ & $2010-2016$ \\
\hline
\end{tabular}

\begin{tabular}{|c|c|c|c|c|c|c|}
\hline \begin{tabular}{lr}
\multicolumn{2}{c}{ Initial } \\
GDP per \\
capita in \\
logs
\end{tabular} & - & $0.0444^{*} * *$ & $0.0185^{* * *}$ & $0.0382^{-} * * *$ & $0.0441^{* * *}$ & $0.0190^{-} * * *$ \\
\hline & $(0.00410)$ & $(0.00692)$ & $(0.00390)$ & $(0.00303)$ & $(0.00498)$ & $(0.00299)$ \\
\hline $\begin{array}{l}\text { Indica- } \\
\text { tor of } \\
\text { economic } \\
\text { complexity }\end{array}$ & $0.038 * * *$ & 0.0195 & $0.058 * * *$ & 0.0146 & 0.0105 & $0.033 * * *$ \\
\hline 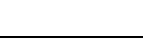 & $(0.0134)$ & $(0.0202)$ & $(0.00884)$ & $(0.0127)$ & $(0.0212)$ & $(0.0113)$ \\
\hline \begin{tabular}{l}
\multicolumn{2}{c}{ Spatial } \\
lag of \\
dep.var.
\end{tabular} & & & & $0.884 * * *$ & $0.251 *$ & $0.677 * * *$ \\
\hline & & & & $(0.0874)$ & $(0.135)$ & $(0.135)$ \\
\hline $\begin{array}{l}\text { Con- } \\
\text { stant }\end{array}$ & $0.448 * * *$ & $0.493 * * *$ & $0.204 * * *$ & $0.383 * * *$ & $0.478 * * *$ & $0.197 * * *$ \\
\hline & $(0.0404)$ & $(0.0688)$ & $(0.0386)$ & $(0.0300)$ & $(0.0493)$ & $(0.0297)$ \\
\hline $\begin{array}{l}\text { Obser- } \\
\text { vations }\end{array}$ & 191 & 191 & 191 & 191 & 191 & 191 \\
\hline $\begin{array}{c}\text { R- } \\
\text { squared }\end{array}$ & 0.465 & 0.323 & 0.192 & & & \\
\hline
\end{tabular}




\section{Conclusions and directions for future research}

In this study we have analysed the patterns of convergence, in terms of structural change and GDP per capita across 191 regions part of the EU28. The analysis has been conducted adopting an original perspective of relatedness measured as the pairwise correlation between the distributions of wages paid in 55 economic branches in each region. This procedure has allowed constructing a spatial econometric model, encompassing also proximity in terms of similarity of the regional production fabrics. Based on such classification, we have studied the patterns of structural change in the network, over the period 2010-2016.

Our results confirm that the patterns of convergence across EU regions are mainly driven by the rapid growth in terms of GDP per capita of Eastern European regions. In addition to this, it shows that such patterns have been accompanied to a marked shift towards more complex manufacturing activities. One possible explanation of this success story experienced in Central and Eastern European regions could be represented by the great participation of FDI especially originating from Germany (Crescenzi et al 2017). Economic complexity of the production systems has helped the Eastern European regions to catch up in the early 2000s, but has also contributed to widen the gap between German regions and the rest in the years following the economic crisis of 2008.

Future research should investigate the drivers underlying the patterns of structural change further, in order to identify the triggers and obstacles for the upgrade of economic structures across territories. This should provide precious insights and bring better practices in areas that would otherwise result trapped into social and economic backwardness. 


\section{$6 \quad$ References}

1. Albeaik, S., Kaltenberg, M., Alsaleh, M., Hidalgo, C.A.: Improving the Economic Complexity Index, Working Paper (https://arxiv.org/abs/1707.05826), (2017).

2. Anselin, L: Spatial Econometrics: methods and models. Dordrecht Kluwer Academic Publishers, Boston (1998)

3. Anselin L., Bera A.: "Spatial Dependence in Linear Regression Models with an application to Spatial Econometrics. In A. Ullah and D.E.A. Giles (Eds.), Handbook of Applied Economics Statistics, Springer Verlag, pp. 21- 74, Berlin (1998).

4. Anselin L. and D. Griffith: Do spatial effects really matter in regression analysis?. Papers in Regional Science, 65, pp. 11-34, (1988).

5. Arbia, G., Basile, R. and Piras, G.:Using Spatial Panel Data in Modelling Regional Growth and Convergence, Working Paper 55, ISAE, (2005).

6. Arrow, K.: Economic Welfare and the Allocation of Resources for Invention. In Arrow K. (ed.), The Rate and Direction of Inventive Activity : Economic and Social Factors, Princeton University Press, Princeton, pp. 609- 625, reprinted in Arrow, Collected Papers, Vol. 5, pp. 104-120, (1962a).

7. Arrow, K.: The Economic Implications of Learning by Doing. Review of Economic Studies, Vol. 29, pp. 155-173, reprinted in Arrow, Collected Papers, Vol. 5, pp.157181(1962b).

8. Arrow K.: Knowledge, Productivity, and Practice, Bulletin SEDEIS, Etude no. 909, Suppl., reprinted in Arrow, Collected Papers, Vol. 5, pp. 191-200, (1965).

9. Barro, R. J., Sala-i-Martin X.: Convergence Across States and Regions, Brookings Papers on Economic Activity, Vol. No.1,pp. 107-182, (1991).

10. Barro, R. J.; Sala-i-Martin, X.: Technological diffusion, convergence and growth, Journal of Economic Growth, 2, pp. 1-16, (1997).

11. Barro, R. J. and Sala-i-Martin, X.: Economic Growth. Second Edition; The MIT Press, Cambridge, Massachussets (2003).

12. Baumol W.J.: Productivity Growth, Convergence and Welfare: What the Long Run Data Show, American Economic Review, 76, pp. 1072-1085, (1986).

13. Beugelsdijk, S., Mariko J.K., Milionis P.: Regional economic development in Europe: the role of total factor productivity, Regional Studies, 52:4, pp.461-476, (2017).

14. Boltho A., Carlin W., Scaramozzino P.: Why East Germany did not become a new Mezzogiorno, Journal of Comparative Economics, 46, pp. 308-325, (2018).

15. Boschma, R.A.: Proximity and innovation: A critical assessment. Regional Studies 39:6174 (2005).

16. Boschma, R.A. and Iammarino S.: Related variety, trade linkages, and regional growth in Italy, Economic Geography, Vol.85, No. 3(Jul., 2009), pp. 289-311(2009).

17. Bosker, M., Buringh E.: City seeds: Geography and the origins of the European city system, Journal of Urban Economics, vol. 98, issue C, pp. 139-157, (2017).

18. Brenner, T. (2006), Identification of Local Industrial Clusters in Germany, Regional Studies, Vol. 40.9, pp. 991-1004.

19. Brock, W. and Durlauf, S. (2001). Growth Empirics and Reality. World Bank Economic Review, 15:229-272.

20. Buccellato, T.: Convergence across Russian regions: a spatial econometric approach, Discussion paper 70, Center for Financial and Management Studies, SOAS, University of London, (2007).

21. Buccellato, T.: The Competences of Firms Are the Backbone of Economic Complexity, SSRN Working Paper, (2016). 
22. Buciuni, G., Corò G., and Micelli S.: Rethinking the role of manufacturing in global value chains: an international comparative study in the furniture industry. Industrial and Corporate Change, 23(4), pp. 967-996, (2014).

23. Corrado, L., Martin, R., and Weeks M.: Identifying and Interpreting Regional Convergence Clusters across Europe. Economic Journal, 115, pp. 133-160, (2005).

24. Crescenzi R., Datu K., Iammarino S.: European Cities and Foreign Investment Networks. Scienze Regionali, Fascicolo 2, maggio-agosto 2017 (doi: 10.14650/86465), (2017).

25. Cuaresma, C.J., Doppelhofer, G., Feldkircher, M.: The determinants of economic growth in European regions. Regional Studies, 48 (1). pp. 44-67. ISSN 1360-0591, (2014).

26. Cristelli, M., Gabrielli A., Tacchella, A., Caldarelli, G., Pietronero, L.: Measuring the intangibles: a metrics for the Economic Complexity of countries and products. PLoS ONE 8, e7072,(2013).

27. Cristelli, M., Tacchella A., Zaccaria A., Pietronero, L.: Growth scenarios for sub-Saharan countries in the framework of Economic Complexity. https://mpra.ub.unimuenchen.de/71594/, (2014).

28. Demertzis M., Sapir A., Wolff G.: Promoting sustainable and inclusive growth and convergence in the European Union. Bruegel Policy Contribution, Issue 7, April (2019).

29. Dosi, G., Grazzi, M., Moschella D.: What do firms know? What do they produce? A new look at the relationship between patenting profiles of product diversification. QuaderniWarking paper DSE N. 1004, (2015).

30. Frenken, K., Van Oort F., Verburg T.: Related Variety, Unrelated Variety and Regional Economic Growth. Regional Studies, Vol. 41.5, pp. 685-697, (2007).

31. Fernihough, A., O'Rourke K. H.: Coal and the European Industrial Revolution. University of Oxford, Discussion Papers in Economic and Social History, No. 124, (2014).

32. Gala, P., Rocha I., Magacho G.: The Structuralist Revenge: economic complexity as an important dimension to evaluate growth and development. Working Paper 436, Sao Paulo School of Economics (2018).

33. Hantsch, S., Kergel, H., Lämmer-Gamp, T., Meier zu Köcker, G., Nerger, M.: German clusters in comparison with European peers. European secretariat of Cluster Analysis and Institute for Innovation and Technology, (2013).

34. Hidalgo, C. A.: Why Information Grows. The evolution of Order, from Atoms to Economy. New York: Basic Books, (2015).

35. Hidalgo, C. A., Haussmann, R.: The building blocks of economic complexity. PNAS, Vol.106, n. 26, 10570-10575, (2009)

36. Hidalgo C. A., Klinger, B., Barabási, A.-L., Hausmann, R.: The product space conditions the development of nations. Science 317, 482 (2007).

37. Hausmann, R., Hidalgo.C.A.: Country diversification, Product Ubiquity, and Economic Divergence. Faculty Research Working Paper Series, Harvard Kennedy School, November, (2010).

38. Hausmann, R., Hidalgo, C. A., Bustos, S., Coscia, M., Chung,. S,. Jimenez, J., Simoes, A., Yıldırım, M. A.: The Atlas of economic complexity - mapping path to prosperity. Center for International Development at Harvard University, Harvard Kennedy School, Macro Connection- MIT Media Lab, MIT, (2011).

39. Iammarino S., Rodriguez-Pose A., Storper M.: Regional inequality in Europe: evidence, theory and policy implications, Journal of Economic Geography. Pp. 1-26 (doi:10.1093/jeg/lby021 ), (2018).

40. Jara-Figueroa C., Jun, B., Glaeser, E.L., Hidalgo C.A.: "The role of industry-specific, occupation-specific, and location-specific knowledge in the growth and survival of new firms". PNAS, December 11, vol. 115, no. 50, (2018). 
41. Kauffman, S.: The Origins of Order: Self-Organization and Selection in Evolution. Oxford University, Oxford, (1993).

42. Kauffman S.: At Home in the Universe: The Search for Laws of Laws of SelfOrganization and Complexity. London: Viking, (1995).

43. Kergel, H., Meier zu Köcker, G., Nerger, M., Ziegler, O.: Cluster management excellence in the Danube region: Pan-European Snapshot of the Current Status of Cluster Management Excellence in Europe. European secretariat of Cluster Analysis (2018).

44. Koren, M., Tenreyro, S.: Technological Diversification. The American Economic Review, Vol. 103, No. 1 (February 2013), pp.3278-414, (2013).

45. Le Gallo J., Ertur, C.: Exploratory spatial data analysis of the distribution of regional per capita GDP in Europe, 1980-1995. Regional Science,Vol 82, Issue 2, pp.175-201, April 2003.

46. Le Gallo J., Ertur, C., Baoumont C.: A spatial Econometric Analysis of Convergence Across European Regions, 1980-1995. in Fingleton, B (ed.), European Regional Growth, SpringerVerlag (Advances in Spatial Sciences), pp.99-129, Berlin, January, 2003.

47. Le Sage, J.P.: Spatial Econometrics. Department of Economics University of Toledo, Circulated for review, December 1998. Rey S.J. and B.D, (1998).

48. Lucas, R.E, on the mechanics of economic development, Journal of monetary Economics 22, pp.3-42, (1988).

49. Rey, S.G., Montouri, B.D.: U.S. Regional Income Convergence: a Spatial Econometric Perspective. Regional Studies 33, 143-156, (2000).

50. Mulder, P. H., De Groot, L.F., Hofkes, M.W.: Economic growth and technological change: A comparison of insights from a neo-classical and an evolutionary perspective. Technological Forecasting \& Social Change, 68, pp. 151-171, (2001).

51. Nelson , R.R., Winter, S., An Evolutionary Theory of Economic Development, Harvard University Press, Cambridge, MA, (1982).

52. O'Brien, P.: The contribution of the periphery. The Economic History Review, New Series, Vol. 35, No. 1, pp. 1-18 (1982).

53. Pavlinek, P.: Foreign direct investment and the development of the automotive industry in Central and Eastern Europe, in: Béla Galgóczi, Jan Drahokoupil and Magdalena Bernaciak (eds) (2015) Foreign investment in eastern and southern Europe after 2008: Still a lever of growth? ETUI, Brussels. ISBN: 978-2-87452-390-8, (2015).

54. Pisano, G. P., Shih, W.C.: Producing Prosperity. Why America Needs a Manufacturing Renaissance, Boston: Harvard Business School Press, (2012).

55. Reinert, E.S.: How Rich Countries Got Rich... and Why Poor Countries Stay Poor, Constable and Robinson Ltd, London, (2007).

56. Rodríguez-Pose A.: The revenge of the places that don't matter, Cambridge Journal of Regions, Economy and Society, 11 (1). pp. 189-209. ISSN 1752- 1378 DOI: 10.1093/cjres/rsx024, (2017).

57. Romer, P.M.: Increasing Returns and Long-Run Growth. The Journal of Political Economy, Vol.94, No.5., pp.1002-1037, (1986).

58. Romer, P.M.: Endogenous Technological Change. The Journal of Political Economy, Vol.98, No.5., pp.s71-s102, October (1990).

59. Sala-i-Martin, X.: The Classical Approach to Convergence Analysis, The Economic Journal, Vol. 106, No. 437, 1019-1036, July, 1996.

60. Solow, R.M.: A Contribution to the Theory of Economic Growth, Quarterly Journal of Economics, 70(1), 65-94, (1956).

61. Stiglitz J.E., Greenwald B.C.: Creating a Learning Society: A New Approach to Growth, Development, and Social Progress, New York: Columbia University Press, (2014) 
62. Swan, T.W.: Economic Growth and Capital Accumulation, Economic Record, 32, 334361, (1956).

63. Tacchella, A., Cristelli, M., Caldarelli, G., Gabrielli, A., and L. Pietronero, A new metrics for countries' Fitness and products' Complexity. Scientific Reports 2, 723, (2012). 